\title{
Hacia el estudio del cierre en la novela árabe: el ejemplo marroquí
}

\author{
Towards the Study \\ of Closure in the Arabic Novel: \\ The Case of the Moroccan Novel
}

\section{FRANCISCO M. RODRÍGUEZ SIERRA*}

Resumen: Se ofrece una aproximación al estudio del cierre en la novela marroquí moderna en lengua árabe entre los años 1930 y 2000. Con base en los estudios de Marco Kunz sobre la novela en lengua española, se examinan los segmentos finales de 126 novelas marroquíes, de los que se extraen los recursos terminativos más decisivos y se propone una tipología. Tradicionalmente, el estudio del final en la narrativa se ha centrado en el desenlace como resolución de las tensiones argumentales y como elemento que completa el sentido global del texto; sin embargo, desenlace y cierre no suelen coincidir. El examen detallado de los cierres de las novelas en su serie histórica permitiría poner de relieve la evolución de ciertas tendencias formales durante el desarrollo del género en Marruecos.

Palabras clave: literatura árabe; novela marroquí; cierre narrativo; recursos terminativos; Marruecos.

Abstract: This article explores final segments in modern Moroccan novels written in Arabic between 1930 and 2000. Following the model of Marco Kunz's studies of the Spanish novel, this paper examines ending segments from 126 Moroccan novels. The more relevant techniques of closure are brought out, and a typology is proposed. Traditionally the study of closure in narrative has focused

Recepción: 26 de noviembre de 2015. / Aceptación: 27 de abril de 2016.

* Universidad Autónoma de Madrid, franciscom.rodriguez@uam.es 
on the outcome and resolution of plot tension and the completion of the overall meaning of the text; however, closure and ending rarely coincide. The analysis of ending devices from these in historical sequence throws into relief some formal trends in the development of the genre in Morocco.

Key words: Arabic literature; Moroccan novel; narrative closure; ending resources; Morocco.

\section{Introducción}

En su trabajo seminal sobre el cierre de la novela, Marco Kunz alude a cierta carencia en el estudio de este elemento de la estructura narrativa, que define como "la descripción de los recursos técnicos que crean en el lector la impresión de que realmente se ha acabado algo al llegar él al punto terminal del libro", ${ }^{1}$ quizá porque nada parece más simple que un punto final y las frases que le anteceden, y porque la mayoría de los estudios se centran en la interpretación del final y su implicación en el sentido del texto completo y el "análisis de la estructura teleológica del texto”. ${ }^{2}$ Los estudios de Frank Kermode y de Julia Kristeva ${ }^{3}$ pueden ser ejemplos de ambas líneas de trabajo. Kunz establece una distinción de partida entre conceptos que tocan el mismo fenómeno y que suelen confundirse: cierre, desenlace, epílogo, apéndice, acabamiento y clausura, que define como sigue:

Entendemos por cierre el final del texto, por desenlace el final de la historia narrada (con o sin solución de conflictos), por epílogo y apéndice diversos tipos de paratextos añadidos al cuerpo principal de la novela, por acabamiento el estado definitivo de una obra que su autor considera como terminada, y por clausura el carácter completo y satisfactorio de la obra en cuanto entidad estética. ${ }^{4}$

Kunz dedica un capítulo a cada uno de estos términos para delimitarlos teóricamente, como paso previo a lo más interesan-

\footnotetext{
${ }^{1}$ Marco Kunz, El final de la novela. Teoría, técnica y análisis del cierre en la literatura moderna en lengua española, Madrid, Gredos, 1997, p. 21.

${ }^{2}$ Idem.

${ }^{3}$ Frank Kermode, The Sense of an Ending, Nueva York, Oxford University Press, 2000 [1966]; Julia Kristeva, Semiótica 1, Madrid, Fundamentos, 2001 [1969], pp. 179-185.

${ }^{4}$ Kunz, El final de la novela, op. cit., p. 19.
} 
te de su estudio, que es la propuesta de una tipología del cierre en la novela moderna en lengua española. Así, en el capítulo dedicado al cierre, Kunz define este concepto como "el verdadero final del texto, su remate definitivo, es decir el último segmento antes del vacío que sigue al punto final. Con esto queda establecido dónde termina el cierre, pero no en qué lugar empieza". ${ }^{5}$

Es decir: el final engloba cierre y desenlace, y el desenlace no suele encontrarse en el último segmento: "un final no es necesariamente un cierre, pero todo cierre es un final, mejor dicho, es el final del final". ${ }^{6}$ Estas precisiones no siempre se han tenido en cuenta al estudiar el final de la narración. La distinción entre final y cierre fue delimitada claramente por Barbara Herrnstein Smith, ${ }^{7}$ cuyas reflexiones, aunque enfocadas en la poesía, pueden ser extrapoladas a otros géneros. ${ }^{8}$ Carlos Reis y Ana Cristina Lopes recogen las entradas desenlace y epílogo, y definen el primero como "evento o conjunto de eventos que, al término de una acción narrativa, resuelve tensiones acumuladas a lo largo de la acción". ${ }^{9}$ Por su parte, Valles Calatrava recoge las entradas desenlace, siguiendo a Reis y Lopes, y final - no recogido por éstos-, donde se dice: "el fin, desenlace o catástrofe suele ocupar el eslabón final que cierra la estructura compositiva de la acción". ${ }^{10} \mathrm{El}$ Oxford Dictionary of Literary Terms, en su edición de 2008, recoge la entrada closure, que define como "el sentido de compleción o resolución al final de una obra o parte de ella [...] o en crítica literaria, la reducción del significado de una obra a un sentido sencillo o completo que excluye otras interpretaciones"; y añade: "el contraste entre textos 'cerrados' y 'abiertos' ha sido un lugar común de la

${ }^{5}$ Ibid., p. 28.

${ }^{6}$ Ibid., p. 34.

${ }^{7}$ Barbara Herrnstein Smith, Poetic Closure. A Study of How Poems End, ChicagoLondres, University of Chicago Press, 1970.

${ }^{8}$ Así opina Marco Kunz, quien afirma que muchos elementos de la tipología de recursos terminativos presentada por él aparecen ya en el citado trabajo de Barbara Herrnstein Smith para la poesía, y en el de Helmut Bonheim (The Narrative Modes: Techniques of the Short Story, Cambridge, D. S. Brewer, 1982) para el relato corto. Véase Kunz, El final de la novela, op. cit., pp. 380-381.

${ }^{9}$ Carlos Reis y Ana Cristina Lopes, Diccionario de narratología, Salamanca, Ediciones Colegio de España, 1996, p. 58.

${ }^{10}$ José Valles Calatrava, Diccionario de teoría de la narrativa, Granada, Ediciones Alhulia, 2002, p. 374. 
crítica moderna". ${ }^{11}$ En esta línea, el trabajo de Eyal Segal en torno a los finales de la narrativa policiaca distingue entre ending y closure, apoyándose precisamente en Barbara Herrnstein Smith, de modo que el primer término sería "un fenómeno inevitable (y por tanto 'obvio'), ya que todo texto narrativo tiene que acabar en alguna parte", y el segundo, "no el propio punto textual de acabamiento, sino más bien un cierto efecto, o cualidad de la percepción, producido por el texto". ${ }^{12}$ Así, lo relevante del final o acabamiento de un texto narrativo es la sensación de resolución que afecta la interpretación global del texto en la medida en que soluciona el desarrollo de la trama, que en ese punto se detiene y completa la interpretación del argumento, con descarte de otras hipótesis que aquí dejan de tener sentido; $y$, por otra parte, se insiste en el desenlace y fin del argumento, que no tiene por qué encontrarse en el cierre del relato ni incluir el punto final.

Se trata del segmento final del texto, cuyo fin conocemos (el punto final, seguido del blanco de la página o el vacío), pero cuyo comienzo no es fácil a veces delimitar, de manera simétrica a lo que sucede con el íncipit, del que se sabe dónde comienza pero no su extensión. Así, Mortara Garavelli afirma, desde el ámbito de la retórica, que la conclusión - del cierre-es "en ciertos aspectos un reflejo simétrico al de los inicios", ${ }^{13} \mathrm{sin}$ precisar más. Cita Kunz el estudio de Guy Larroux ${ }^{14}$ al abordar la dificultad de la delimitación del final, tal vez por la debilidad demarcativa al proponer a veces el texto unidades muy extensas (novelas sin capítulos, etcétera) y a que en muchos casos las divisiones tipográficas y lógicas no son coincidentes. Larroux opta por el último capítulo como base de la delimitación, lugar donde se producirían los últimos cambios y que mantiene una fuerte relación de articulación con el resto del texto. No obstante,

${ }^{11}$ Chris Baldick, Oxford Dictionary of Literary Terms, Oxford, Oxford University Press, 2008, p. 60.

${ }_{12}$ Eyal Segal, "Closure in Detective Fiction", Poetics Today, vol. 31, núm. 2, 2010, p. 155.

${ }_{13}$ Bice Mortara Garavelli, Manual de retórica, Madrid, Gredos, 1991 [1988], p. 117.

${ }^{14}$ El estudio de Guy Larroux de 1987 citado por Kunz, "Le mot de la fin ou la clôture romanesque en question", es la tesis doctoral de tercer ciclo, Université Sorbonne Nouvelle, 1987. Larroux trata este asunto más brevemente en "Mise en cadre et clausularité”, Poétique, núm. 98, 1994, pp. 247-253. 
afirma Kunz que la delimitación del segmento final —el cierrees cuestión "irresoluble", que el último capítulo resulta a veces una unidad demasiado extensa y, siguiendo a Torgovnick, ${ }^{15}$ que "[p]odemos considerar como segmento final una palabra, una frase, un párrafo o un capítulo entero"; $;{ }^{16}$ y concluye que la “extensión ideal" no debería exceder una o dos páginas". ${ }^{17}$ Así, opta por "cierta elasticidad" en la delimitación del cierre, toda vez que "nos interesará menos la cuestión de la frontera interna que el establecimiento del inventario de esas señales terminales y su interpretación en cada ejemplo concreto". ${ }^{18}$ Es decir, que lo irresoluble de la delimitación no debe distraer de lo relevante, a saber, los mecanismos de resolución de la narración, y ello ante la previsión de que, dado el carácter creativo del fenómeno y su probable variedad de formas, el límite anterior sea lábil, poroso y, en gran medida, irrelevante.

La importancia del cierre, al igual que la del incipit, reside en que es un punto privilegiado; su percepción como señal de demarcación, ${ }^{19}$ como moldura ${ }^{20}$ lo sitúa "en una posición estructural fuerte", ${ }^{21}$ dado que "las estructuras artísticas están llamadas por su naturaleza a una clara delimitación del mensaje. El 'fin' y el 'principio' se hallan aquí mucho más marcados que en los mensajes del lenguaje común". ${ }^{22}$ Más claramente expresado por Kunz: "las últimas palabras alcanzan en la conciencia del receptor una mayor presencia [...] Esta potencialidad resonante inherente al cierre aumenta la impresión subjetiva que tiene el lector de la importancia del segmento terminal del texto y favorece la retrospección interpretativa". ${ }^{23}$

${ }^{15}$ Marianna Torgovnick, Closure in the Novel, Princeton, Princeton University Press, 1981.

${ }^{16} \mathrm{Kunz}$, El final de la novela, op. cit., p. 29.

${ }^{17}$ Ibid., p. 37.

${ }^{18}$ Ibid., p. 31.

${ }_{19}$ Philippe Hamon, "Clausule”, Poétique, núm. 24, 1975, pp. 495-526.

${ }^{20}$ Boris Uspensky, A Poetics of Composition. The Structure of the Artistic Text and Typology of a Compositional Form, Berkeley, California University Press, 1973, pp. 137 y ss.

${ }^{21}$ Yuri Lotman, Estructura del texto artístico, Madrid, Istmo, 1978 [1970], p. 72.

${ }^{22}$ Yuri Lotman y Escuela de Tartú, "Valor modelizante de los conceptos de ‘fin' y 'principio'”, en Yuri Lotman y Escuela de Tartú, Semiótica de la cultura, Madrid, Cátedra, 1979 [1970], p. 202.

${ }^{23} \mathrm{Kunz}$, El final de la novela, op. cit., p. 161. 


\section{La reflexión sobre el final en la crítica árabe}

El incipit ha merecido cierto interés en la reflexión sobre la novela árabe, ${ }^{24}$ pero el cierre lo ha sido en menos ocasiones. Sabry Hafez (Ṣabry Hāfiz) aborda la cuestión en el marco de sus observaciones a la novela Hadit al-Qaryah, en su conocido estudio The Genesis of Arabic Narrative Discourse, en cuyo último epígrafe, "The Open Ending and Its Significance”, concluye que los finales "son normalmente divididos en finales cerrados y abiertos", y los primeros se anuncian con la repetición "de algunos elementos previos de forma diferente, o por medio de mecanismos de cierre tales como la marcha del personaje de la escena de la historia, o el cierre de puertas, ventanas, o incluso de vidas, por medio de la muerte". ${ }^{25}$

Por su parte, en los finales abiertos "los conflictos [...] se dejan irresueltos [...] La acción queda suspendida más que concluida"; y, citando a Helmut Bonheim, sugiere que Mahmūd Tāhir Lāš̀in, autor de Hadît al-Qaryah, era consciente de que “en el siglo xx los finales abiertos habían devenido más o menos la estrategia estándar”. ${ }^{26} \mathrm{Hafez}$ parece manejar el concepto de final (ending) como la suma de los conceptos de desenlace $\mathrm{y}$ cierre, no como remate textual, y relaciona un tipo $\mathrm{u}$ otro de final narrativo con la evolución de la sensibilidad estética.

Encontramos también referencias al final de la novela en Infitāḥ al-naṣs al-riwā'̀̀. Al-Nașs wa-l-siyāq (La apertura del texto novelístico. La novela y el contexto), de Said Yaqtin ( $\mathrm{Sa}{ }^{‘} \overline{1} \mathrm{~d}$ Yaqtīn), cuando, al estudiar cinco novelas árabes, ${ }^{27}$ retoma las

${ }^{24}$ Véase, por ejemplo, Sabry Hafez, "al-Bidāyāt wa-waz̄ifatu-hā fi-l-nașs al-qișșị” (Los inicios y su función en el texto narrativo), Al-Karmel, núms. 21-22, 1986; Šu ‘ayb Halīīi, "Wazịfat al-bidāya fi-l-riwāya al-'arabiyya", Al-Karmel, núm. 61, 1999, pp. 85106; Tania al-Saadi, "Évolution des 'ouvertures' des romans arabes au cours du $\mathrm{Xx}^{\mathrm{e}}$ siècle”, Arabica, núm. 56, 2009, pp. 61-89; Nūr al-Dīn Șadūq, al-Bidāya fi-l-nașs al-riwēà (El inicio en el texto novelístico), al-Lāziqiyya, al-Ḥiwār, 1994.

${ }^{25}$ Sabry Hafez, The Genesis of Arabic Narrative Discourse. A Study in the Sociology of Modern Arabic Literature, Londres, Saqi Books, 1993, p. 255. Mi traducción.

${ }^{26}$ Ibid., p. 256.

${ }^{27}$ Al-Zaynī Barakāt, de Gamal al-Ghitani; 'Awdat al-Tā'ir ilá al-baḅr (El regreso del pájaro al mar), de Halim Barakat; Anta mund al-yawm (Tú desde el día de hoy),

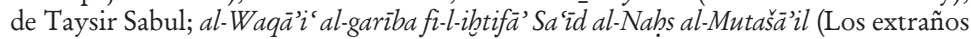
sucesos de la desaparición de Said, el pesoptimista), de Emil Habibi; y Al-Zaman alMuwaḥ̣aš (La época siniestra), de Haydar Haydar. 
palabras finales de cada una de ellas, y afirma que los finales de los respectivos discursos anuncian de manera directa, o casi directa, los finales significativos de las respectivas historias. Se centra Yaqtin en esas obras situadas cronológicamente en los años posteriores a la derrota árabe de 1967, entre 1969 ('Awdat al-Tä’ir ilá al-bahrr) y 1974 (Al-Zaynī Barakāt), y estudia cómo esa realidad extratextual se refleja en el cuerpo de los relatos y en sus finales, que giran sobre la idea de la derrota, y cómo se construyen según estructuras cerradas o abiertas. ${ }^{28}$ Yaqtin se ocupa del final de la novela en cuanto ayuda a configurar una determinada interpretación del texto en su conjunto, pero no trata el asunto de una tipología del cierre.

Más recientemente, Abdelmalik Ashhabun ('Abd al-Mālik Ašhabūn) publicó un interesante estudio sobre el principio y el fin en la novela árabe, en cuya bibliografía sólo se recogen tres artículos dedicados al final: uno en árabe de 'Abd al-Fattāh al-Haŷmarī ${ }^{29}$ además de los ya mencionados de Philippe Hamon y de Guy Larroux. La posición de Ashhabun no difiere de lo visto hasta ahora: distingue entre nihāya (fin o clausule) y bătima (clôture o cierre), y afirma que "el final juega un papel esencial en la legibilidad (o ilegibilidad) del texto novelístico". ${ }^{30}$ Toma su definición de bătima ${ }^{31}$ de la ya aportada por Guy Larroux, a saber, como "estrategias globales de organización [...] una espacialidad (activa) del texto [...] efectos de lectura $\mathrm{y}$ de sentidos", ${ }^{32} \mathrm{y}$ define el final como "ese lugar en el que se supone que se completa el ciclo de acontecimientos, tanto desde el punto de vista del escritor como del receptor". ${ }^{33}$ Por lo demás, la tipología de finales ofrecida por Ashhabun se centra en la distinción del final trágico (al-nibāya al-másāroiyya) y el $f i$ nal feliz (al-nibāya al-sa ìda), y en la preeminencia de un tipo u

${ }^{28}$ Said Yaqtin, Infitāḥ al-naș al-riwā'̄ (La apertura del texto novelístico), Casablanca-Beirut, al-Markaz al-T Taqāfī al-'Arabī, 2001, pp. 72-74.

29 'Abd al-Fattāh al-Haŷmarī, "al-Bidāya wa-l-Nihāya fi-l-Riwāya al-Magribiyya" (El principio y el final en la novela marroquí), 'Alāmāt, núm. 8, 1997.

30 'Abd al-Mālik Ašhabūn, al-Bidāya wa-l-nihāya fi-l-riwāya al-'arabiyya (El principio y el fin en la novela árabe), El Cairo, Ru’ya li-l-našr wa-l-tawzí‘ , 2013, p. 234. Mi traducción.

${ }^{31}$ Ibid., p. 240.

${ }^{32}$ Larroux, "Mise en cadre et clausilarité", op. cit., p. 251.

${ }^{33}$ Ašhabūn, al-Bidāya wa-l-nihāya..., op. cit., p. 241. 
otro según modas y subgéneros, como la necesidad de un final dramático en novelas románticas y de un final feliz para el héroe en las novelas de evasión. ${ }^{34}$ En suma, el interés por el $f i$ nal se da en cuanto intérprete del texto completo, donde final se confunde con desenlace y el cierre queda fuera de foco.

\section{Delimitación del género de la novela árabe en Marruecos}

La delimitación temporal del género de la novela en Marruecos ha estado siempre en permanente discusión. Roger Allen planteó recientemente la revisión del límite inicial, es decir, decidir cuál es el texto inaugural del género. Siguiendo las reflexiones de críticos marroquíes como Muhammad Barrada y citando a Fernández Parrilla, ${ }^{35}$ propone Allen "retrasar el reloj temporal y explorar la manera en que narraciones anteriores (y diferentes tipos de narrativas) proporcionan o no precedentes para desarrollos posteriores". ${ }^{36}$

Durante los años sesenta y setenta fue considerada novela inaugural Fi-l-Tufüla (De la niñez, 1957), de 'Abd al-Maŷīd Ben Ŷellūn, y se obvió su carácter autobiográfico por la "euforia nacionalista" del momento, que aupaba una novela de contenido patriótico surgida en el periodo de la independencia de Marruecos, en 1956. ${ }^{37}$ Más tarde, durante los años ochenta, Dafan-nā al-mā derado el primer texto novelístico maduro al cobrar relevancia cierto concepto artístico de la novela frente al social-realista de la etapa previa. ${ }^{38}$ En esa década, si bien se convenía en que Dafan-nā al-mádì era la novela "que da[ba] cuerpo a las carac-

${ }^{34}$ Ibid., pp. 253-277.

${ }^{35}$ Gonzalo Fernández Parrilla, La literatura marroquí contemporánea. La novela y la crítica literaria, Cuenca, Universidad de Castilla-La Mancha, 2006.

${ }^{36}$ Roger Allen, "Rewriting Literary History: The Case of Moroccan Fiction in Arabic", The Journal of North African Studies, núm. 16, vol. 3, 2011, p. 314. Mi traducción.

${ }^{37}$ La novela fue publicada de manera seriada en la prensa en los años previos.

${ }^{38}$ Véase Fāṭima al-Zahrā' Azrwīl, Mafāhìm naqd al-riwāya bi-l-Magrib. Mașādi-ruhā al-'arabiyya wa-l-aŷnabiyya (Conceptos de la crítica novelística en Marruecos. Sus fuentes árabes y extranjeras), Casablanca, Maṭba'at al-Naȳāh al-Ŷadīda, 1989, pp. 4954. 
terísticas completas de la novela en Marruecos”, ${ }^{39}$ durante el Congreso sobre la Novela Marroquí celebrado en Rabat en 1984 el crítico Ahmad al-Yaburi (Ahmad al-Yābūrī) defendió el carácter novelístico de textos anteriores, como al-Zäwiya $(\mathrm{La}$ zagüía, 1942), de Tuhami al-Wazzani (al-Tuhāmī al-Wazzānī), y Wazìr Garnāta (El visir de Granada, 1950), de Abdelhadi Butalib ('Abd al-Hādì Būtālib), el segundo como un intento de novela histórica y el primero como texto autobiográfico "cuasi novelístico". ${ }^{40} \mathrm{La}$ consecuencia de esta reflexión fue la inserción de La zagüía en los listados bibliográficos de la novela marroquí en lengua árabe, pese al reconocimiento de su carácter autobiográfico.

Así, ya en el número 3-4 de la revista $\bar{A} f a ̄ q$, donde se publicaban los artículos del citado congreso celebrado en 1984, se incluye una bibliografía de la novela en Marruecos, firmada por Mustafà Yaalà (Mustafà Ya'là), ${ }^{41}$ que remonta su inicio a 1930 con al-Rị̣la al-Marrākušiyya aw mir'āt al-masāwì al-waqtiyya (Viaje por Marruecos, o el Espejo de las desgracias de la época), de Muhammad bn 'Abd Allāh al-Mu'aqqit, y que incluye, además, La zagüía; es decir, justo los dos textos apuntados por Roger Allen como precedentes para un estudio del género de la novela marroquí en lengua árabe. Conviene notar, al hilo de los cambios en las convenciones en torno al canon literario del género, que Abd al-Rahim al-Allam ('Abd al-Rahīm al-'Allām) elaboró en el año 2000, en una publicación de la Asociación de Escritores Marroquíes, una bibliografía de la novela marroquí en la que expresamente "se incluyen textos autobiográficos" -entre ellos La zagüía - con el argumento de que, al aceptar esto, "la novela entre nosotros sería hija de la autobiografía, al tiempo que la autobiografía ha sido considerada hija de la novela en Europa". ${ }^{42}$

${ }^{39}$ Ahmad al-Madīnī, Fi-l-adab al-magribī al-mu'āsirir (Sobre la literatura marroquí contemporánea), Casablanca, Dār al-Našr al-Magribiyya, 1985, p. 44.

${ }^{40}$ Ahmad al-Yābūrī, "Takawwun al-ḩițāb al-riwā'î: al-riwāya al-magribiyya namūdaŷan" (La formación del discurso novelístico: la novela marroquí como ejemplo), $\bar{A} f \bar{a} q$, núms. 3-4, 1984, p. 14.

${ }_{41}$ Abdallāh Muwaddan y Muștafà Ya'alà, "Bibliyūgrāfiyya al-fann al-riwā’ì bi-lMagrib (1930-1984)" (Bibliografía del género novelístico en Marruecos), Āfāq, núm. 34, 1984, pp. 74-82.

42 'Abd al-Rahīm al-'Allām, al-Riwāya al-magribiyya bi-l-'arabiyya. Min al-ta’sis 


\section{Examen de los recursos de cierre narrativo}

La limitada producción novelística en Marruecos hasta los años noventa facilita la obtención de datos más globales y un mejor ajuste del panorama del género. El examen que aquí se presenta estudia datos parciales en serie, buscando estructuras y tendencias en el desarrollo de un fenómeno cultural en una zona geográfica concreta -Marruecos, en este caso-. No se trata, en términos relativos, de un gran volumen de datos, pero sí del examen del cierre de un número significativo de novelas escritas en árabe en Marruecos hasta el año 2000, lo que permite observar el surgimiento y el desarrollo de ciertos rasgos formales de los que se pueden derivar consecuencias, quizá ya conocidas o intuidas. Por ejemplo, la vinculación de finales especulares, o del cambio de registro con la inserción de poemas, con las tendencias de novela experimental que aparecieron con fuerza en Marruecos entre los años setenta y ochenta. ${ }^{43}$

El número de las novelas examinadas es lo suficientemente amplio como para fundamentar una tipología y que el cuadro aportado resulte útil. El análisis pormenorizado de los cierres refleja mi lectura atenta de los segmentos finales. He detectado recursos y estrategias terminativas simultáneas en un mismo segmento, pero he decidido, en lo posible, centrarme en dos o tres de estos elementos con el único criterio de su relevancia. Según los casos, algunos elementos han sido obviados por poco potentes en relación con otros más determinantes - de cara al lector - como señales de final y cierre. Cabe admitir que un examen llevado a cabo por otro lector podría haber mostrado variaciones. Hay que reconocer, como el propio Kunz hace,

ilà al-imtidādāt. Bībliogrāfiyya: 1942-1999 (La novela marroquí en árabe. Fundación y alcance. Bibliografía 1942-1999), Casablanca, Manšūrāt Ittihād Kuttāb al-Magrib, 2000 , p. 6. La traducción es mía. Sobre autobiografía y novela, véase también Azrwīl, Mafähim..., op. cit., pp. 100-110.

${ }^{43}$ Este trabajo se inspira modestamente en el "distant reading" de Franco Moretti para el estudio de la historia de la literatura a través de datos cuantitativos en su desarrollo cronológico, con el fin de deducir estructuras y tendencias, sin depender siempre de la lectura detallada de los propios textos. Moretti afirma que su idea inicial era aludir a su método como "serial reading", pero la etiqueta "distant reading" fue la que tuvo finalmente éxito, quizá como contrapartida del "close reading”. Véase Marco Moretti, Distant Reading, Londres-Nueva York, Verso, 2013. 
que a menudo intentar detectar los elementos terminativos en el cierre implica una apreciación subjetiva del lector y, en este caso, del investigador. Ponderado ese riesgo, los elementos observados contienen esa potencialidad que el lector -y por tanto el investigador- puede llegar activar o no por diversos motivos. Lo importante es que "si queda demostrado que un elemento textual determinado puede, por sus cualidades intrínsecas, funcionar como una señal del final, entonces es un recurso terminativo". ${ }^{44}$

La terminología usada se inspira en la tipología de Marco Kunz, en la convicción de que el esquema tiene cabida en otras literaturas y en otros géneros artísticos. ${ }^{45}$ Examiné un total de 123 novelas en un rango de tiempo que va desde 1930 hasta el año 2000. Es un número nada desdeñable, dado el volumen históricamente reducido del género novelístico, comparado con el de Egipto o Líbano, por ejemplo. En la ya mencionada bibliografía de Abd al-Rahim al-Allam, editada por la Unión de Escritores de Marruecos, y por tanto “oficial”, por así decirlo, el número total de obras recogidas es de 249 entre 1942 y 1999.

Al-Allam precisa que en el listado aparecen obras que técnicamente son autobiografías. Es éste un tema sensible en la crítica literaria marroquí. Textos narrativos que bordean los límites ficcionales y que podrían incluirse en el espacio autobiográfico como novelas autobiográficas o autobiografías noveladas, siempre de límites difusos y permeables, aparecen en diferentes épocas y contextos. ${ }^{46}$ Piénsese en textos como alZäwiya (1942), Fi-l-tufūla (1956) o al-Hubz al-hāầ (El pan desnudo, 1982). Al-Allam no es el único: en la clásica bibliografía de Mustafà Yaalà, ya mencionada, la inclusión de textos autobiográficos es normal. Ambas bibliografías no coinciden en las obras recogidas. Por ejemplo, en el listado de Yaalà de 1984 y en otro del mismo autor de $2002^{47}$ se recogen nada menos que

${ }^{44} \mathrm{Kunz}$, El final de la novela, op. cit., p. 382.

${ }^{45}$ Ibid., pp. 380-381.

${ }^{46}$ V'éase 'Abd al-Qādir al-Šāwī, al-Kitāba wa-l-wnȳūd. Al-Sìra al-d̄ātiyya fi-l-Magrib (La escritura y la existencia. La autobiografía en Marruecos), Casablanca, Ifriqiya-Šarq, 2000, donde, apoyándose en la idea del pacto autobiográfico en la línea estructuralista de Philippe Lejeune, repasa las formas autobiográficas en Marruecos, delimita el género, y estudia como autobiografía textos comúnmente considerados como novelas.

${ }^{47}$ Muștafá Ya'alà, al-Sard al-Magribī 1930-1980. Bībliyūgräfiyya mutabașsissa (La na- 
GRÁFICA 1. Desarrollo de la producción novelística en Marruecos de 1942 a 1999

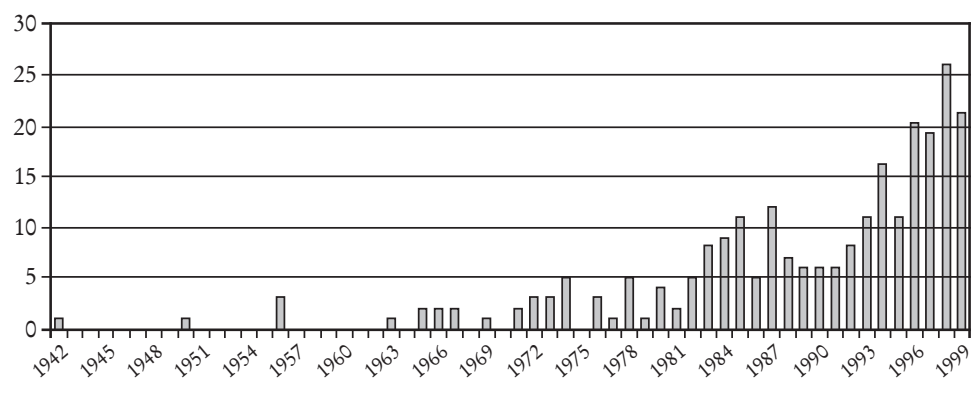

Fuente: Abdel Rahim al-Allam, al-Riwaya al-Magribiyya bi-l-Arabiyya, Casablanca, Manšūrāt Ittihạād Kuttāb al-Magrib, 2000, pp. 21-40.

17 novelas aparecidas de manera seriada en la prensa entre 1944 y 1955 y que al-Allam omite, por ejemplo Thăhā (1941), de Ahmad al-Hasan al-Sakūrī; o al-Rūmiyya al-Šaqrā' (La cristiana rubia, 1949), de 'Abd al-'Azīz bn 'Abdallāh, etcétera. He optado por situar el umbral inicial del arco temporal abarcado en el año 1930, con al-Riḅla al-Marrākušiyya, de Muhammad bn 'Abdallāh al-Mu'aqqit, como hace Yaalà. Las 249 novelas recogidas en la bibliografía de al-Allam entre 1942 y 1999 se distribuyen como se observa en la gráfica 1.

Según al-Allam, hasta el año 1976, es decir, "treinta años después de la aparición del primer texto", la producción es irregular, con años en blanco. ${ }^{48}$ Los vacíos son numerosos: de 1943 a 1949, de 1951 a 1955, de 1957 a 1962, 1964, 1968, 1970 y 1975. Hasta el año 1982 no se alcanza un mínimo de cinco novelas anuales. Finalmente, se observa un asentamiento a partir de la mitad de los años noventa del siglo pasado. La continuidad de este incremento se observa en listados que abarcan fechas posteriores, como el de Muhammad Yahyá Qāsimī (gráfica 2), donde desde 1941 hasta 1999 —es decir, en 59 años- lista 309 novelas, cifra que posteriormente casi se alcanza, con otras 284

rrativa marroquí 1930-1980. Una bibliografía especializada), Casablanca, Šarikat alnašr wa-l-tawzī‘ al-Madāris, 2002, pp. 91-114.

${ }^{48}$ Al-'Allām, al-Riwāaya, op. cit., p. 6. 
Gráfica 2. Desarrollo de la producción novelística en Marruecos de 1941 a 2007

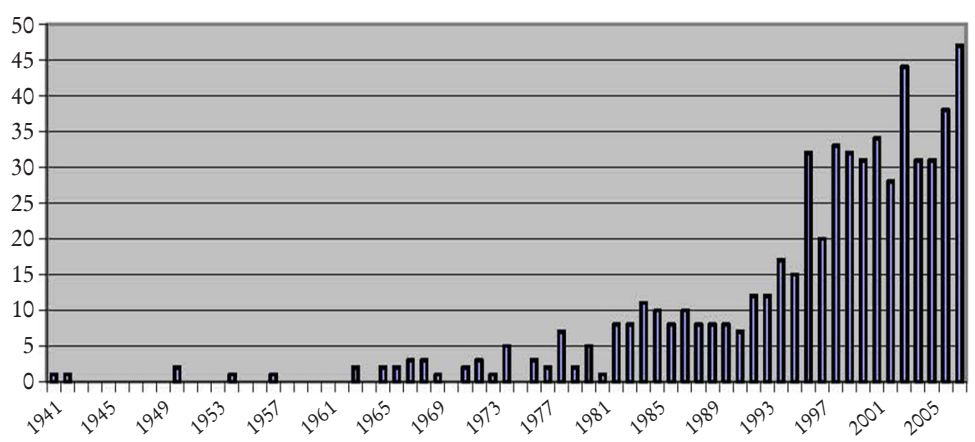

Fuente: Muḥammad Yahyà Qāsimī, al-Adab al-magribì al-mu'āsir (1926-2007), Rabat, Manšūrāt Wizārat al-Ṭaqāfa, 2009.

novelas, en el periodo mucho más breve que media entre 2000 y $2007 .{ }^{49}$

Pese a que los listados no coinciden exactamente, y a que algún texto de carácter autobiográfico puede o no ser considerado ficción o a que una lista dé cuenta de alguna novela que apareció publicada sólo de manera seriada, la producción irregular es generalizada hasta 1976, y escasa con cierto estancamiento hasta la década de los noventa. En su estudio sobre el contexto sociocultural de la novela marroquí de lengua árabe, Muhammad al-Dagmumi (Muhammad al-Dagmūmī) une tal irregularidad con "la inconcreción en la especialización" de los escritores, ${ }^{50} \mathrm{y}$ con las condiciones socioeconómicas y materiales del ámbito editorial, de producción y consumo del libro, que impiden la profesionalización, pues el creador no encuentra tiempo ni medios para una dedicación más o menos completa, y su producción acaba limitada "a uno o dos títulos, y luego calla”. ${ }^{51}$ Así, según la bibliografía de al-Allam, en 1975 había

${ }^{49}$ Muhammad Yahyà Qāsimī, al-Adab al-magribī al-mu'āsirir (1926-2007) (La literatura marroquí contemporánea [1926-2007]), Rabat, Manšūrāt Wizārat al-Taqāfa, 2009.

${ }^{50}$ Muhammad al-Dagmūmī, al-Rirwāya al-magribiyya wa-l-tagayyur al-î̀timā̄i $(\mathrm{La}$ novela marroquí y el cambio social), Casablanca, Afrīqiyā/Šarq, 1991, p. 41.

${ }^{51}$ Ibid., p. 54. 
GRÁFICA 3. Novelas examinadas en este estudio distribuidas por año

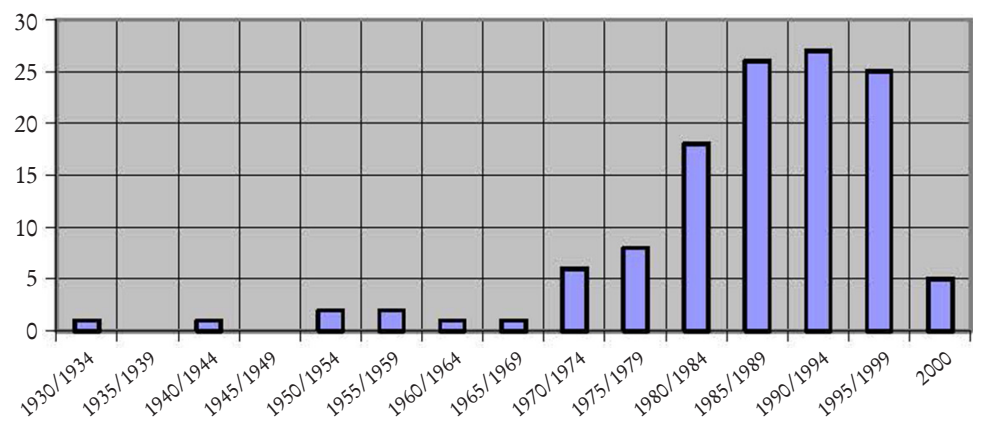

sólo un escritor con tres novelas; en 1980, dos escritores con tres novelas y otros dos con cuatro; hacia 1985 los números se incrementaban hasta uno con cuatro novelas, dos con cinco, uno con seis y otro con siete novelas; en 1990 ya había cuatro novelistas que firmaban cuatro novelas, tres con cinco novelas, uno con seis y dos con siete. Para entonces, los novelistas con una o dos obras eran muchos. Los casos más prolíficos tienen más que ver con una larga carrera creativa que con una intensa producción -'Abd al-Karīm Gallāb, Muhạmmad Zafzāf o Mubārak Rabī'-, por más que puntualmente encadenen obras en años sucesivos.

Nuestra selección de novelas abarca $49 \%$ de los textos recogidos por al-Allam, lo cual supone un corpus estimable. ${ }^{52} \mathrm{La}$ distribución por fechas de los textos examinados muestra una tendencia similar a la de los listados de al-Allam y de Yaalà, como se observa en la gráfica 3 .

Considero, pues, que el corpus de textos estudiado es representativo, no sólo del conjunto global de la producción novelística en lengua árabe en Marruecos, sino también de su evolución cuantitativa.

${ }^{52}$ El criterio de selección ha sido la mera disponibilidad de acceso a los textos. 


\section{Propuesta de tipología del cierre}

Del análisis realizado de las 123 novelas publicadas entre 1930 y 2000 - aunque de este último año sólo haya examinado cinco del total de las 31 que cita Qāsimī- se extrae la tipología que se detalla.

\section{Propuesta de tipología de elementos terminativos}

1. Elementos externos

1.1. Elementos tipográficos (estrellas; puntos suspensivos).

1.2. Fecha y lugar.

1.3. Palabra "final" (normalmente /intahat/).

2. Elementos internos

2.1. Señales paratextuales del final inminente.

2.1.1. Título del último capítulo: por ejemplo, "final" (/bātima/).

2.1.2. Fórmula de despedida.

2.2. Señales no paratextuales del final inminente

2.2.1. Fórmula de despedida del propio narrador.

2.2.2. Recursos epilogales.

2.2.3. Fotos y documentos.

2.3. Resonancia del final

2.3.1. En contenido: quintaesencia.

2.3.1.1. Frase sentenciosa.

2.3.1.2. Retrospección.

2.3.1.3. Totalización (condensación del conjunto).

2.3.2. En recursos estilísticos

2.3.2.1. Recursos expresivos.

2.3.2.2. Dialectalismo; modificación del registro.

2.3.2.3. Pregunta retórica.

2.3.2.4. Repeticiones: léxicas, aliteraciones.

2.3.2.5. Construcciones sintácticas: ausencia de puntuación; paralelismos, etcétera.

2.4. Procesos finalizadores 
2.4.1. Cierre $=$ desenlace o final.

2.4.2. Elementos cinéticos (movimientos finales: ascenso, descenso, desplazamiento en general).

2.4.3. Marcador temporal.

2.4.4. Campo semántico "final” (apocalipsis; "acabar", etcétera).

2.4.5. Compleción subordinada.

2.4.6. Congelación de la escena (freezing).

2.4.7. Disminución de sensaciones (fading).

2.5. Procesos no finalizadores (relatividad del carácter concluso)

2.5.1. Alusión a continuidad.

2.5.2. Alusiones al futuro.

2.6. Final y marco narrativo

2.6.1. Circularidad.

2.6.1.1. Regreso al marco narrativo.

2.6.1.2. Alusión al principio.

2.6.1.3. Repetición del título al final (o palabra[s] clave del título en las líneas finales.

2.6.2. Confusión de mundos diegéticos.

2.6.3. El narrador se dirige al lector.

Esta tipología se inspira en la de Marco Kunz, pero se limita a lo observado en los textos examinados. En primer lugar establezco una distinción entre elementos que permanecerían en el margen del texto como obra artística. Kunz, siguiendo a Barbara Korte, califica estos recursos como "éticos" o externos, frente a "émicos" o internos. ${ }^{53}$ Se trata de establecer el límite entre lo que caería dentro del texto como objeto artístico y lo que quedaría fuera y resultaría, por lo tanto, relativamente cambiante y sujeto a decisiones editoriales. Apunta Kunz también a la dificultad de establecer los límites en la medida en que, a veces, el propio autor puede jugar con ellos.

En la otra gran división, los elementos internos, distingo entre: i) señales paratextuales que anuncian sin equívoco el final del texto, cuyo ejemplo más obvio es que el último capítulo se

${ }^{53}$ Kunz, El final de la novela, op. cit., p. 143. 
titule "final”, "conclusión" o algo similar; ii) señales no paratextuales del final, como sería una fórmula estereotipada de despedida del narrador; o la aportación de fotos y documentos ficcionales en el segmento final (como en el caso muy evidente de Imìlš̌ll, de Sa'īd 'Alū̌̌ [1980]); iii) lo que denomino, tomado de Kunz, "resonancia del final", pero distinguiendo cuando se resalta el contenido y cuando tal resonancia proviene de recursos expresivos; iv) procesos finalizadores: desde la coincidencia del cierre con desenlace y final (como en $A$-yantabi al-harīq [¿Acabará el incendio?], de 'Alī al-Fīlāl [1998]) hasta la recurrencia de términos del campo semántico "final”, o el recurso a la "compleción subordinada" (o "subordinate completion"), entendida por Stevick como una pequeña acción o evento final (una reunión, la búsqueda de un objeto en un cajón, una conversación previa a la despedida, etcétera), no siempre dependiente de un esquema mayor, cuyos elementos terminativos se aprovechan para cerrar la novela; ${ }^{54}$ términos como freezing y fading están tomados también de Kunz; v) procesos no finalizadores, es decir, aquellos que aluden a una continuidad, pese a que simultáneamente marcan el inminente cierre; y vi) aquellos elementos que afectan el marco narrativo al efectuar movimientos circulares o especulares con salidas de niveles hipodiegéticos hacia la narración marco, o al confundir niveles narrativos o, frecuentemente, repetir al final palabras clave del título o el título mismo. Obviamente, hay que entender que estos elementos terminativos suelen darse simultáneamente.

\section{Coda}

Este estudio contiene un elemento subjetivo por cuanto se trata de mi lectura de los finales, en la que cabrían variaciones lógicas según los diferentes lectores. Se ha intentado paliar este elemento subjetivo con el acceso a un número importante de textos -123 novelas- en una distribución temporal armóni-

${ }^{54}$ Phillip Stevick, "Open Ends", The Chapter in Fiction: Theories of Narrative Division, Siracusa, Syracuse University Press, 1970, pp. 57-73. Citado por Kunz, El final de la novela, op. cit., p. 169. Compárese la descripción del final abierto que hace Hafez en The Genesis..., op. cit., p. 255, y que cité más arriba. 
ca con la realidad global de la producción novelística en Marruecos. Con todo, habría que ser prudente con las consecuencias deducibles del examen: pese a superar la centena de textos, no se sobrepasó ni siquiera la mitad de los publicados entre 1930 (o 1941, según los listados) y 1999 (con algunos pocos textos ya de 2000), rango temporal al que me circunscribí. Por ello, el examen debería servir más bien para sugerir tendencias.

Así, el rasgo de la circularidad, normalmente expresado con la repetición del título o de palabras clave del mismo en las líneas finales, tiende al alza a principios de los años ochenta y noventa. Hasta los años setenta, los textos examinados son tan pocos, año a año, que el resultado sería poco significativo. Pero si, entre 1971 y 1975 , de siete novelas un solo texto ofrece ese rasgo, ${ }^{55}$ y entre 1976 y 1980 lo muestran dos de $10,{ }^{56}$ entre 1981 y 1985 son ya seis de 20,57 entre 1986 y 1990 bajan a tres de $27,{ }^{58}$ para saltar de nuevo a 11 de 25 entre 1991 y $1995,{ }^{, 9}$ y moderarse nuevamente entre 1996 y 1999 con sólo cuatro textos. ${ }^{60}$ Puede haber lagunas y no están todos los textos, pero si nuestra muestra es numéricamente significativa, la tendencia es obvia. El recurso aparece por primera vez con Inna-hā al-ḩayāt (Es la vida, de Ismā̄îl Abū'inānī, circa 1963), una de las obras

${ }^{55}$ Hāŷiz al-taly (El muro de nieve), de Sa'īd 'Alūšs.

${ }^{56} \dot{A}$ brāŷy al-madina (Las torres de la ciudad), de Muhammad 'Izz al-Dīn al-Tāzī; y Al-Dal' wa-l-ŶYazira (La costilla y la isla), de al-Mīlūdī Šagmūn.

${ }^{57}$ Las novelas son: Al-Hubz al-Hāfì (El pan desnudo), de Muhammad Šukrīi; Raḅil al-baḥr (La marcha del mar), de Muhammad 'Izz al-Dīn al-Tāzī; A Á̀y $\bar{a}$ 'lā tantahì (Cosas que no acaban), de 'Abd al-Qādir al-Samīh; Hayra, de Ahmad Benŷallūl; Al-Ta lab al-lādi yazhar wa-yabtafī (El zorro que aparece y desaparece), de Muhammad Zafzāf; y $A l$-Warda wa-l-baḥr (La rosa y el mar), de Idrīs Belmalīh.

${ }^{58}$ Lu'bat al-nisyān (El juego del olvido), de Muhammad Barrāda; Al-Mabä’a (El lazareto), de Muhammad 'Izz al-Dīn al-Tāzīi y Hayāt salāhîif(Vida de tortugas), de Hašìmī Ahmad.

${ }^{59}$ Las novelas son: Ayyām al-rimād (Días de ceniza), de Muhammad 'Izz al-Dīn al-Tāzīi Hubb fī hayy al-safīh (Amor en el barrio de chabolas), de Tiulū' al-Muștafá; $A l$ Hayy al-bुalfī (El barrio de atrás), de Muhammad Zafzāf; Baḅr al-zalamāt (El mar oscuro), de Muhammad al-Dagmūmī; Al-Fưqdān (La pérdida), de 'Abd al-Rahịm Bahīr; Sana bayn al-qițārayn (Un año entre dos trenes), de 'Abd al-Wahāb al-Rāmī; Šurūb fi-l-mirāyā (El espejo rajado), de 'Abd al-Karīm Gallāb; Tarīq al-saḅāb (El camino de las nubes), de Ahmad al-Madīnī; Zaman al-Šärwiya (El tiempo de Shawiya), de Šu'ayb Halîfī; Raml fì al-deākira (Arena en la memoria), de Ahmad Ŷazūlī; y Firāq fì Tanŷa (Separación en Tánger), de 'Abd al-Hayy Muwaddan.

${ }^{60}$ Zagārìd al-maret (Albórbolas de muerte), de 'Abd al-Karīm Ŷuytī; $\hat{Y}$ asad wamadina (Cuerpo y ciudad), de Zahūr Karam; Al-Bawm (El búho), de ' $\overrightarrow{\mathrm{A}}$ 'yša Mūqiz; y Rä’ḥat al-ŷanna (El aroma del paraíso), de Šu'ayb Halífī. 
que el crítico marroquí Muhammad Barrada consideró hace años como una de las cuatro "novelas fracasadas" (al-riwaayāt al-fäšlla), debido a su "penuria técnica" (al-iqdā' al-fannì), que vieron la luz entre la publicación de Fi-l-Tufüla (De la niñez, 1956) y Dafannā al-mādì (Hemos enterrado el pasado, 1966). ${ }^{61}$ La repetición del título al final, un recurso metatextual que "contiene la definición más concisa posible del libro" y supone un modo de recapitular y condensar el mensaje del texto, ${ }^{62}$ se percibe también como elemento circular al activar su carácter de moldura, simultáneamente tanto al principio como al final del texto, lo que potencia su función. Las oscilaciones de este recurso, tal como se describe aquí, podrían interpretarse en su momento de auge como el gusto por el juego metatextual que busca la complicidad del receptor en momentos de ascenso de la experimentación literaria, como en el Marruecos de principios de los años ochenta, y de desgaste del mismo con el paso de la ola experimental con la llegada del nuevo siglo.

Otro rasgo observable, por ejemplo, es la prevalencia del recurso de "compleción subordinada". Se trata de la típica escena final tras el desenlace y de importancia irrelevante para efectos argumentales, pero que ayuda a poner fin al relato: una conversación entre personajes antes de despedirse, una reunión, la lectura de una carta, una noticia radiada o televisada, etcétera; en suma, un evento menor que acaba con el cierre del relato. Se percibe como elemento epilogal que muestra el devenir cotidiano de personajes y eventos una vez resuelta la tensión de la trama. En mi listado aparece por primera vez con Dafannā al-mādì (1966), que a su vez es la única novela del listado del quinquenio 1966-1970. En los cinco años siguientes (1971-1975), la compleción subordinada aparece en dos textos de los siete listados; ${ }^{63}$ no aparece en las 10 novelas de la lista entre 1976 y 1980; y resurge con fuerza a partir de entonces: siete de 20 entre 1981

${ }^{61}$ Muhammad Barrada, "al-Usus al-nażariyya li-l-riwāya al-magribiyya al-maktūba bi-1-“arabiyya” (Los fundamentos teóricos de la novela marroquí escrita en árabe), 1969. Usé la versión que aparece como anexo en 'Abd al-Kabīr al-Hatīibī, al-Rirwāya al-magribiyya (La novela marroquí), Rabat, Manšūrāt al-Markaz al-Ŷāmi‘î̀ li-1Baht al-'Ilmī (Publicaciones del Centro Universitario de Investigación), 1971.

${ }^{62} \mathrm{Kunz}$, El final de la novela, op. cit., pp. 205-205.

${ }^{63}$ Al-Mu'allim 'Alī, de 'Abd al-Karīm Gallāb; y Arsîfa wa-ŷydrān (Aceras y paredes), de Muhammad Zafzāf. 
y $1985 ;{ }^{64}$ seis de 27 entre 1986 y 1990; ${ }^{65}$ siete de 25 entre 1991 y $1995 ;{ }^{66}$ para finalmente bajar entre 1996 y 1999, con tres de 21 novelas. ${ }^{67}$ Cabría interrogarse sobre la razón de tal comportamiento de un recurso habitual en la narrativa fílmica y televisiva y que parece asentarse conforme se asientan las claves del propio género.

Para acabar, sería interesante ahondar aún más en esta línea de trabajo, aumentando el número de novelas estudiadas en el caso marroquí y abarcando la producción de otros países árabes. Ante la imposibilidad práctica de estudiar con detalle el texto de cada novela de la producción de un país, el examen de series de rasgos permite, sin embargo, una mirada transversal y abarcadora que revela estructuras y desarrollos en la vida del género.

\section{Dirección institucional del autor:}

Facultad de Filosofía y Letras

Universidad Autónoma de Madrid

Ciudad Universitaria de Cantoblanco

c/ Tomás y Valiente, 1

28049, Madrid, España

${ }^{64} \mathrm{Al}$-Ablah wa-l-Mansiya wa-Yāsmīn (El tonto, la olvidada y Yasmín), de al-Mìlūdī Šagmūn; Warda li-l-waqt al-magribī (Una rosa para el tiempo marroquí), de Ahmad al-Madīnī; al-Huanāzir (Los cerdos), de Yūsuf Fādil; Baydat al-dīk (El huevo dèl gallo), de Muhammad Zafzāf; Hayra, de Ahmad Benŷallūl; Ali-Sanawāt al-îỹäf (Años de vacas flacas), de Muhammad Șūf; y Dahälìz al-yayš al-qadìm (Las galerías del antiguo ejército), de Laḥmadānī Hamịd.

${ }^{65}$ Kāna wa-abawātu-hā (Kana y sus hermanas), de 'Abd al-Qādir al-Šāwī; Al'Išăal-Suflī (La cena inferior), de Muhammad al-Šarakī; Al-Mun'ataf (La curva), de al-Habīb al-Dā'im Rabbī; 'Ayn al-faras (El ojo del caballo), de al-Mìlūdī Šagmūn; Min taqub al-bāb (Por el agujero de la puerta), de Būšu'ayb al-Sūfānī; y Al-Raŷul al-laḍi lā zill la-bu (El hombre sin sombra), de Muhammad Šakìr.

${ }^{66}$ Ishāāhāt min sifr al-qatì'a (Correcciones al libro), de Muhammad al-Ahsāynī;

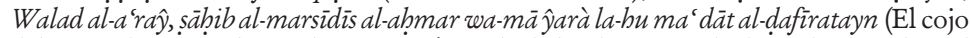
del mercedes rojo y lo que le aconteció con la de las dos trenzas), de Muhammad Sa'ìd Sūsān; Bạ̣r al-zalamāt (El mar oscuro), de Muhammad al-Dagmūmī; Al-Fuqdān (La pérdida), de 'Ab̉bd al-Rahīm Bahīr; Al-taslīm (El talismán), de 'Abd Allāh al-Hamdūš̄̄; Halūsāt tarš̌̌̌s (La obsesión), de Hassūna al-Miṣbāḥī; y Šâ̂arat al-b̧allāta (El árbol de la estupidez), de al-Mìlūdī Šagmūn.

${ }^{67}$ Zaman al-aḅlām al-dă'i' (El tiempo de los sueños perdidos), de 'Abd al-Salām Sulaymān; Ŷanūb al-rūh (El sur del alma), de Muhammad al-Ašsarī; y Afwāh wāsi'a (Bocas anchas), de Muḥammad Zafzāf. 


\section{Bibliografía}

'ABD al-Fattāḥ al-Haŷmarī, "al-Bidāya wa-l-Nihāya fi-l-Riwāya al-Magribiyya”, 'Alāmāt, núm. 8, 1997.

'Allām (AL-), 'Abd al-Rahīm, al-Riwāya al-magribiyya bi-l-'arabiyya. Min al-tà siss ilà al-imtidādāt. Bībliogrāfiyya: 1942-1999, Casablanca, Manšūrāt Ittihāè Kuttāb al-Magrib, 2000.

Allen, Roger, "Rewriting Literary History: The Case of Moroccan Fiction in Arabic", The Journal of North African Studies, núm. 16, vol. 3, 2011, pp. 311-324. DOI: 10.1080/13629387.2010.550725.

AšHabūn, 'Abd al-Mālik, al-Bidāya wa-l-nihāya fi-l-riwāya al-'arabiyya, El Cairo, Ru'ya li-l-našr wa-1-tawzī', 2013.

Azrwīl, Fātima al-Zahrā', Mafābìm naqd al-riwāya bi-l-Magrib. Masādiru-hā al-'arabiyya wa-l-âynabiyya, Casablanca, Maṭba'at al-Naȳāh al-Ŷadīda, 1989.

BALDICK, Chris, Oxford Dictionary of Literary Terms, Oxford, Oxford University Press, 2008.

BonheIm, Helmut, The Narrative Modes: Techniques of the Short Story, Cambridge, D. S. Brewer, 1982.

DAGMŪMĪ, Muhammad, al-Riwāya al-magribiyya wa-l-tagayyur alî̀timā̄ ${ }^{c}$, Casablanca, Afrīqiyā/Šarq, 1991.

Fernández PARrilla, Gonzalo, La literatura marroquí contemporánea. La novela y la crítica literaria, Cuenca, Universidad de Castilla-La Mancha, 2006.

Hafez, Sabry, "al-Bidāyāt wa-waẓîfatu-hā fi-l-naṣṣ al-qiṣaṣī", Al-Karmel, núms. 21-22, 1986.

Hafez, Sabri, The Genesis of A rabic Narrative Discourse. A Study in the Sociology of Modern Arabic Literature, Londres, Saqi Books, 1993.

HaLī̄ī, Šua'ib, "Wazịfat al-bidāya fi-l-riwāya al-'arabiyya", Al-Karmel, núm. 61, 1999, pp. 85-106.

Hamon, Philippe, "Clausule”, Poétique, núm. 24, 1975, pp. 495-526. HुAṬīī (AL-), 'A bd al-Kabīr, al-Riwāya al-magribiyya, Rabat, Manšūrāt al-Markaz al-Ŷàmi'ī li-l-Baht al-'Ilmī, 1971.

Herrnstein Smith, Barbara, Poetic Closure. A Study of How Poems End, Chicago-Londres, University of Chicago Press, 1970.

Kermode, Frank, The Sense of an Ending, Nueva York, Oxford University Press, 2000 [1966].

Kristeva, Julia, Semiótica 1, Madrid, Fundamentos, 2001 [1969].

Kunz, Marco, El final de la novela. Teoría, técnica y análisis del cierre en la literatura moderna en lengua española, Madrid, Gredos, 1997.

Larroux, Guy, "Mise en cadre et clausularité”, Poétique, núm. 98, 1994, pp. 247-253. 
Larroux, Guy, "Le mot de la fin ou la clôture romanesque en question", tesis doctoral de tercer ciclo, Université Sorbonne Nouvelle, 1987.

LoTMAN, Yuri y Escuela de Tartú, "Valor modelizante de los conceptos de “fin' y 'principio'”, en Yuri Lotman y Escuela de Tartú Semiótica de la cultura, Madrid, Cátedra, 1979 [1970], pp. 199-203.

Lotman, Yuri, Estructura del texto artístico, Madrid, Istmo, 1978 [1970].

MADīNì (AL-), Ahmad, Fi-l-adab al-magribī al-mu'äsìr, Casablanca, Dār al-Našr al-Magribiyya, 1985.

MoretTi, Franco, Distant Reading, Londres-Nueva York, Verso, 2013.

Mortara Garavelli, Bice, Manual de retórica, Madrid, Gredos, 1991 [1988].

MuwadDAN, Abdallāh y Ya'alà, Mustafá, "Bibliyūgrāfiyya al-fann alriwā'ì bi-l-Magrib (1930-1984)”, Áfāq, núm. 3-4, 1984, pp. 74-82.

QĀsIMĪ, Muhammad Yahyà, al-Adab al-magribí al-mu'ạsirir (1926-2007), Rabat, Manšūrāt Wizārat al-Ṭaqāfa, 2009.

ReIS, Carlos y Ana Cristina Lopes, Diccionario de narratología, Salamanca, Ediciones Colegio de España, 1996.

SAADI (AL-), Tania, “Évolution des 'ouvertures' des romans arabes au cours du xx siècle", Arabica, núm. 56, 2009, pp. 61-89.

ṢAdŪQ, Nūr al-Dīn, al-Bidāya fi-l-nașs al-riwā'̀̄, Al Lāziqiyya, AlHiwār, 1994.

ŠĀWì (AL-), 'Abd al-Qādir, al-Kitāba wa-l-wnŷūd. Al-Sīra al-dātiyya fi-l-Magrib, Casablanca, Ifriqiya-Šarq, 2000.

Segal, Eyal, "Closure in Detective Fiction”, Poetics Today, núm. 31 (2), 2010, pp. 153-215. DOI: 10.1215/03335372-2009-018.

Torgovnick, Marianna, Closure in the Novel, Princeton, Princeton University Press, 1981.

Uspensky, Boris, A Poetics of Composition. The Structure of the Artistic Text and Typology of a Compositional Form, Berkeley, California University Press, 1973.

Valles Calatrava, José, Diccionario de teoría de la narrativa, Granada, Alhulia, 2002.

YĀBŪRİ (AL-), Aḥmad, “Takawwun al-ḩițāb al-riwā'î: al-riwāya al-magribiyya namūdaŷan”, Áfāq, núms. 3-4, 1984, pp. 13-19.

YA 'LÀ, Muștafá, al-Sard al-Magribi 1930-1980. Bïbliyūgrāfiyya mutahașsișa, Casablanca, Šarikat al-našr wa-l-tawzī' al-Madāris, 2002.

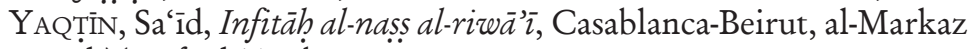
al-Taqāfī al-'Arabīi, 2001. 


\section{Anexo: Finales en novelas marroquíes de lengua árabe (1930-2000)}

\begin{tabular}{|c|c|c|}
\hline Año & Novela / Autor & Características / Tipo de final \\
\hline 1930 & $\begin{array}{l}\text { Al-Riḅla al-Marrākušiyya, } \\
\text { aw mir'at al-masāwì al- } \\
\text { waqtiyya, wa yusammà } \\
\text { aydan al-sayf al-maslūl } \\
\text { 'alì al-ma'rad'an sunnat } \\
\text { al-Rasūl / Muhammad ben } \\
\text { 'Abd Allāh al-Mu'aqqit }\end{array}$ & "Fin”. Fórmula de despedida. \\
\hline 1942 & $\begin{array}{l}\text { Al-Zāwiya / al-Tuhāmī al- } \\
\text { Wazzānī }\end{array}$ & $\begin{array}{l}\text { Fórmula de despedida (“final de la } \\
\text { primera parte"). Sentencia } \\
\text { religiosa. }\end{array}$ \\
\hline 1950 & $\begin{array}{l}\text { Salīl al-taqalayn /al-Tuhāmī } \\
\text { al-Wazzānī }\end{array}$ & $\begin{array}{l}\text { "Fin". Fecha. Elemento cinético } \\
\text { finalizador (ascenso). }\end{array}$ \\
\hline 1950 & $\begin{array}{l}\text { Wazìr Garnāta / 'Abd al- } \\
\text { Hādī Būṭālib' }\end{array}$ & $\begin{array}{l}\text { Tipografía (tres estrellas). Recursos } \\
\text { epilogales (“y así acaba”); regreso al } \\
\text { marco narrativo principal. }\end{array}$ \\
\hline 1956 & $\begin{array}{l}\text { Fi-l-tufūla / 'Abd } \\
\text { al-Maŷìd bn Ŷ́allūn }\end{array}$ & $\begin{array}{l}\text { Capítulo “final”. Recursos } \\
\text { epilogales (mirar atrás); alusión a } \\
\text { elemento inicial (la cara de la Luna). }\end{array}$ \\
\hline 1957 & $\begin{array}{l}\text { Rabis al-ḥayāt / Muhammad } \\
\text { al-Haḍar al-Raysūnī }\end{array}$ & $\begin{array}{l}\text { Procesos finales (“y por la } \\
\text { mañana"). Resonancia del final: } \\
\text { atmósfera patética. }\end{array}$ \\
\hline 1963 & $\begin{array}{l}\text { Inna-bā al-ḥayāt / Ismā'‘̄il } \\
\text { Abū'inānīi }\end{array}$ & $\begin{array}{l}\text { "Colofón" (/bātima/); fecha } \\
\text { y lugar. Circularidad: título } \\
\text { en frase final. Narrador se dirige } \\
\text { al lector. }\end{array}$ \\
\hline 1966 & $\begin{array}{l}\text { Dafan-nā al-mādī / 'Abd } \\
\text { al-Karīm Gallāb }\end{array}$ & $\begin{array}{l}\text { Compleción subordinada } \\
\text { (conversación en el cementerio). } \\
\text { Anuncio, nuevo comienzo. } \\
\text { Circularidad: título al final. }\end{array}$ \\
\hline 1971 & $\begin{array}{l}\text { Al-Mu'allim 'Alī / 'Abd al- } \\
\text { Karīm Gallāb }\end{array}$ & $\begin{array}{l}\text { Tipografía (estrellas). Compleción } \\
\text { subordinada (personajes leen la } \\
\text { prensa y conversan brevemente). } \\
\text { Anuncio. }\end{array}$ \\
\hline 1971 & $\begin{array}{l}\text { Al-Gurba / 'Abdallāh al- } \\
\text { 'Aruwī }\end{array}$ & $\begin{array}{l}\text { Tipografía. Campo semántico (la } \\
\text { noche). Elemento cinético (entra en } \\
\text { la mezquita). Carácter inconcluso. }\end{array}$ \\
\hline
\end{tabular}


AnExo: (continuación)

\begin{tabular}{|c|c|c|}
\hline Año & Novela / Autor & Características / Tipo de final \\
\hline 1972 & $\begin{array}{l}\text { Al-Mar'a wa-l-warda / } \\
\text { Muhammad Zafzāf }\end{array}$ & $\begin{array}{l}\text { Cambio de diálogo a prosa, de } \\
\text { presente a pasado; modificación } \\
\text { registro; elemento finalizador } \\
\text { (regreso). }\end{array}$ \\
\hline 1973 & $\begin{array}{l}\text { Arssifa wa-ŷdrān / } \\
\text { Muḥammad Zafzāf }\end{array}$ & $\begin{array}{l}\text { Compleción subordinada } \\
\text { (despedida); campo semántico final } \\
\text { (dejar; suicidio; vagar sin rumbo); } \\
\text { elementos cinéticos (dejar, vagar, } \\
\text { salir). }\end{array}$ \\
\hline 1974 & Bāmū / Aḥmad Zayyād & Retrospección. \\
\hline 1974 & Hāŷiz al-talŷy / Sa'īd 'Alūš & $\begin{array}{l}\text { Circularidad: título al final. } \\
\text { Fórmula de despedida. }\end{array}$ \\
\hline 1975 & $\begin{array}{l}\text { Rifqat al-silāh wa-l-qamr / } \\
\text { Mubārak Rabīi }\end{array}$ & $\begin{array}{l}\text { Poema. Tipografía: centrado de } \\
\text { l'́neas. }\end{array}$ \\
\hline 1976 & $\begin{array}{l}\text { Zaman bayn al-wiläda wa-l- } \\
\text { bulm / Aḥmad al-Madīn̄i }\end{array}$ & Poema. \\
\hline 1978 & $\begin{array}{l}\text { Al-Rīh al-Šitäwriyya / } \\
\text { Mubärak Rabī‘ }\end{array}$ & $\begin{array}{l}\text { Tipografía (tres estrellas); título } \\
\text { al final; modificación registro } \\
\text { (dialectalismo); resumen. }\end{array}$ \\
\hline 1978 & $\begin{array}{l}\text { Qubūr fi-l-mā'/ } \\
\text { Muḥammad Zafzāf }\end{array}$ & $\begin{array}{l}\text { Tipografía (bātima); anuncio; } \\
\text { eliminación de estímulos. }\end{array}$ \\
\hline 1978 & $\begin{array}{l}\text { Al-Yatìm / 'Abdallāh al- } \\
\text { 'Aruwī }\end{array}$ & $\begin{array}{l}\text { Recurso tipográfico no verbal } \\
\text { (espaciado); elemento cinético; } \\
\text { dialectalismo; pregunta } \\
\text { retórica. }\end{array}$ \\
\hline 1978 & $\begin{array}{l}\text { Abräŷal-madina / } \\
\text { Muhamammad 'Izz al-Dīn al- } \\
\text { Tāzì }\end{array}$ & $\begin{array}{l}\text { Recursos retóricos (sintaxis). } \\
\text { Retrospección. Proceso finalizador } \\
\text { (ascenso del agua hasta la asfixia). } \\
\text { Circularidad: repetición } \\
\text { título. }\end{array}$ \\
\hline 1978 & $\begin{array}{l}\text { Al-Ma'raka al-Kubrà / } \\
\text { Muhammad Bn Aḥmad } \\
\text { Ašmā'ū }\end{array}$ & Sentencia. Alusiones al futuro. \\
\hline 1979 & $\begin{array}{l}\text { Al-Af'à wa-l-bahbr / } \\
\text { Muhammad Zäzzāf }\end{array}$ & $\begin{array}{l}\text { Fecha; alternancia realidad- } \\
\text { irrealidad, disminución sensaciones } \\
\text { ópticas. }\end{array}$ \\
\hline
\end{tabular}


ANExo: (continuación)

\begin{tabular}{|c|c|c|}
\hline Año & Novela / Autor & Características / Tipo de final \\
\hline 1980 & 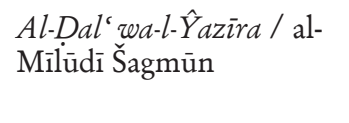 & $\begin{array}{l}\text { Vuelta al marco narrativo; } \\
\text { modificación registro (Qal al-rawi); } \\
\text { carácter inacabado. }\end{array}$ \\
\hline 1980 & $\begin{array}{l}\text { Sa-abkī yarwm tarŷa ìn / } \\
\text { Ahmad 'Abd al-Salām al- } \\
\text { Baqqālī }\end{array}$ & $\begin{array}{l}\text { Tipografía. Declaración inacabada. } \\
\text { Campo semántico final (finalizó, } \\
\text { dejó). }\end{array}$ \\
\hline 1980 & Imìlšil / Sa'īd 'Alūš & $\begin{array}{l}\text { Apéndice (fotos, documentos, } \\
\text { etcétera). Sentencia judicial y } \\
\text { repetición de un mismo sintagma } \\
\text { ("el juego"). }\end{array}$ \\
\hline 1982 & $\begin{array}{l}\text { Al-Hubz al-Hāfī / } \\
\text { Muḥammad Şukrīi }\end{array}$ & $\begin{array}{l}\text { Circularidad: rememoración } \\
\text { evento inicial; paralelismo } \\
\text { y contraste; campo semántico } \\
\text { "final". }\end{array}$ \\
\hline
\end{tabular}

1982 Al-Ablab wa-l-Mansiya wa- Fecha. Compleción subordinada. Yāsmìn / al-Mīlūdī Šagmūn Freezing.

1982 Warda li-l-waqt al-magribī / Compleción subordinada; Aḥmad al-Madīnī elementos cinéticos; campo semántico final.

1982 al-Huanāzir / Yūsf Fādil Lugar y fecha. Compleción subordinada: sale a la calle. Freezing.

1982 Riḅla naḩw al-nūr / Muhammad al-Ȟadar alRaysūnī

Anuncios metanarrativos de final inminente.

1983 Raḥil al-baḥr / Muhammad 'Izz al-Dīn al-Tāzī

Circularidad: título al final; alternancia entre realidad/irrealidad; anuncios seudoparatextuales.

1983 Badr Zamānibi / Mubārak Cambio situación narrativa; final $\mathrm{Rabi}^{-6}$ autoconsciente; modificación registro (poesía y dialecto); campo semántico final.

1983 Al-Zaman al-Muqìt / Idrīs Tipografía. Freezing. al-Ṣagir

1983 Ayyām min 'ads / Būhūšs Tipografía (tres puntos). Alusión Yàsīn al futuro. 
ANExo: (continuación)

\begin{tabular}{|c|c|c|}
\hline Año & Novela / Autor & Características / Tipo de final \\
\hline 1983 & $\begin{array}{l}\text { Ǎ̌y ȳ' lā tantabì / 'Abd al- } \\
\text { Qādir al-Samịh }\end{array}$ & $\begin{array}{l}\text { Circularidad: repetición del título. } \\
\text { Sentencia. }\end{array}$ \\
\hline 1984 & $\begin{array}{l}\text { Baydat al-dìk / Muhammad } \\
\text { Zafzāf }\end{array}$ & $\begin{array}{l}\text { Compleción subordinada; } \\
\text { elementos cinéticos; resumen; } \\
\text { anuncio. }\end{array}$ \\
\hline 1984 & Hayra / Aḥmad Benŷallūl & $\begin{array}{l}\text { Circularidad: repetición del } \\
\text { título. Vocativo y frase; sentencia. } \\
\text { Compleción subordinada (llegada } \\
\text { de dos policías). }\end{array}$ \\
\hline 1984 & $\begin{array}{l}\text { Al-Bi'r / 'Abd al-Fattāḥ al- } \\
\text { Fākihānī }\end{array}$ & $\begin{array}{l}\text { Fecha y lugar. Campo semántico } \\
\text { "final". Fading. }\end{array}$ \\
\hline 1984 & $\begin{array}{l}\text { Al-Madb̧al al-sirrī ilà kahf } \\
\text { al-ḩamām / Ahmad 'Abd } \\
\text { al-Salām al-Baqqālī }\end{array}$ & "Fin". Proceso finalizador: cerrar. \\
\hline 1984 & $\begin{array}{l}\text { Al-Sanawāt al-îyāaf/ } \\
\text { Muhạammad Șūf }\end{array}$ & $\begin{array}{l}\text { Señal paratextual (“Acaba la } \\
\text { novela...”). Compleción secundaria } \\
\text { (aduana en el aeropuerto). }\end{array}$ \\
\hline 1985 & $\begin{array}{l}\text { Al-Ta'lab al-lādī yazhhar wa- } \\
\text { yabtafí / Muḥammad Zafzāf }\end{array}$ & $\begin{array}{l}\text { Anuncio. Circularidad: mención del } \\
\text { título. }\end{array}$ \\
\hline 1985 & $\begin{array}{l}\text { Al-Sūqal-dābilī / } \\
\text { Muhạmmad Šukrī }\end{array}$ & $\begin{array}{l}\text { Fecha y lugar. Modificación } \\
\text { del registro de lengua. Resumen: } \\
\text { lema. }\end{array}$ \\
\hline
\end{tabular}

1985 Muhārwalat $i \check{\imath}$ / Muhammad Anuncio; frase lapidaria. Zafzāf

1985 Dahālìz al-ŷayš al-qadìm / Lahmadānī Hamīd

1985 Al-Warda wa-l-bahr / Idrīs Belmalīh
Fecha y lugar. Compleción subordinada (el protagonista contempla). Freezing.

Circularidad: mención del título. Cambio a la segunda persona. Frase final, sentencia.

$1986 \begin{aligned} & \text { Al-Farīq / 'Abdallāh al- } \\ & \text { 'Aruwīi }\end{aligned} \quad \begin{aligned} & \text { Construcciones sintácticas: último } \\ & \text { párrafo sin puntuar. Resumen. }\end{aligned}$

1986 Kāna wa-abawātu-hā / 'Abd Compleción subordinada al-Qādir al-Šāwi (carta). Ampliación temporal ("sigue..."). 
ANExo: (continuación)

\begin{tabular}{lll}
\hline Año & Novela / Autor & Características / Tipo de final \\
\hline 1986 & $\begin{array}{l}\text { Unšüdat al-qamr / Al-'Arabīì } \\
\text { Benterka }\end{array}$ & $\begin{array}{l}\text { Fecha y lugar. Desenlace. } \\
\text { Sentencia. }\end{array}$ \\
\hline 1987 & $\begin{array}{l}\text { Lu'bat al-nisyān / } \\
\text { Muhạmmad Barrāda }\end{array}$ & $\begin{array}{l}\text { Circularidad: repetición } \\
\text { del título; regreso al marco } \\
\text { narrativo. }\end{array}$ \\
\hline 1987 & $\begin{array}{l}\text { Al-Ŷināza / Ahmad al- } \\
\text { Madīnī }\end{array}$ & $\begin{array}{l}\text { Cita del Corán; campo semántico } \\
\text { final; frase final jaculatoria ("Dios } \\
\text { sabe”). }\end{array}$ \\
\hline
\end{tabular}

1987 Al-'Išảal-Suflī / Muhammad Fecha y lugar. Compleción al-Šarakī subordinada. Procesos cinéticos finales (sale a la calle). Anticipación (“No volverás").

1987 Safr fì anbār al-dēkira / al- Fórmula de despedida. Resumen. 'Arabī Benŷallūn

1987 Al-Qaşba / Idrīs Belmelīh Anuncio al futuro. Exclamación, vocativo.

1987 Al-Mun'ataf / al-Habīb al- Título último capítulo (bātima). Dā'im Rabbī Compleción subordinada.

1987 Zubrat al-b̧arif / Moraleja. Repetición de palabras; Muhammad Abū 'Īda paralelismos.

1988 Al-Mabä'a / Muhammad Mise en abyme: el autor menciona las 'Izz al-Dīn al-Tāzì dos ediciones de la obra.

1988 'Ayn al-faras / al-Mīlūdī Compleción subordinada; Šagmūn movimientos cinéticos finales.

1988 Abläm baqara / Muhammad Modificación registro de lengua; al-Harādi motivo apocalítico (cementerio); frase final: "muuuu".

1988 Bināyat al-sirā" / Ahmad Sentencia ("afirmó su entereza y al-Bakrī al-Sibā'ī su amor a la patria”). Atmósfera patética. Fading.

1988 Min taqbal-bāb / Būšu'ayb Visión del futuro. Compleción al-Šūān̄ì subordinada: embarazo.

1989 Kāzāblānkāa / Muhammad Fecha y lugar; compleción Șüf subordinada; anuncio. 
ANExo: (continuación)

\begin{tabular}{|c|c|c|}
\hline Año & Novela / Autor & Características / Tipo de final \\
\hline 1989 & $\begin{array}{l}\text { Fawq al-qubūr taht al-qamr } \\
\text { / Muhammad 'Izz al-Dīn } \\
\text { al-Tàzìi }\end{array}$ & $\begin{array}{l}\text { Fading. Recursos rítmicos. Motivos } \\
\text { apocalípticos. }\end{array}$ \\
\hline 1989 & $\begin{array}{l}\text { A wrōàq. Sìrat Idrīs al- } \\
\text { dihniyya / 'Abdallāh al- } \\
\text { "Aruwī }\end{array}$ & $\begin{array}{l}\text { Bibliografía final no paratextual. } \\
\text { Campo semántico (muerte). } \\
\text { Resumen. }\end{array}$ \\
\hline
\end{tabular}

1989 Wiā́d al-zawraq ilà al-nab` / Campo semántico final: fin de 'Abd al-Karīm al-Gallāb conversación y despedida.

1989 Safinat al-šabaḥ / Ahmad Fecha y lugar. Regreso y

'Abd al-Salām al-Baqqālī recibimiento.

\begin{tabular}{|c|c|c|}
\hline 1989 & $\begin{array}{l}\text { Fantāziyāa al-ŷyāim / } \\
\text { Muḥammad Büfattās }\end{array}$ & Recurso epilogal (posfacio). \\
\hline 1990 & $\begin{array}{l}\text { Maŷnūn al-ḥukm / Sālim } \\
\text { Ḥimmīs }\end{array}$ & $\begin{array}{l}\text { Notas paratextuales. Cambio } \\
\text { tipográfico (cursiva); modo } \\
\text { discursivo (cita literal). Marcadores } \\
\text { temporales. }\end{array}$ \\
\hline
\end{tabular}

1990 Al-Raŷul al-lad̄ī lā zill la-bu Compleción subordinada (escena / Muḥammad Šakìr en la estación de tren). Fading.

1990 Agāmāt / Yūsuf Fādil $\quad$ Fecha y lugar. Campo semántico final. Alusión a continuación.

1990 Masālik al-Zaytūn / al- Campo semántico final. Repetición Mìlūdī Šagmūn de sintagmas.

1990 Ayyu-bāal-rā̄i / Muhammad Construcción sintáctica (pregunta). 'Izz al-Dīn al-Tāzì Incertidumbre. Elementos cinéticos.

1990 Hayāt salāhif / Hašīmī Anuncios. Circularidad: repetición Àhmad del título.

\begin{tabular}{|c|c|c|}
\hline & $\begin{array}{l}\text { Ruŷu' 'ilà al-tufūla / Laylà } \\
\text { Abū Zayd }\end{array}$ & $\begin{array}{l}\text { Fecha y lugar. Atmósfera patética } \\
\text { ("Mi padre no dijo nada. Se quedó } \\
\text { reflexionando y no dijo nada"). }\end{array}$ \\
\hline
\end{tabular}

1991 Isḩāhāt min sifr al-qatīia/ Compleción subordinada: el Muhạmmad al-Ahsāynī contenido de la última frase ya se conoce y se repite como evento accesorio para finalizar el relato. Recurso retórico: parlamento del personaje. 
ANExo: (continuación)

\begin{tabular}{|c|c|c|}
\hline Año & Novela / Autor & Características / Tipo de final \\
\hline 1992 & $\begin{array}{l}\text { Ayyām al-rimād / } \\
\text { Muhạmmad 'Izz al-Dīn al- } \\
\text { Tāzí }\end{array}$ & $\begin{array}{l}\text { Circularidad: repetición del título. } \\
\text { Resumen, lema. }\end{array}$ \\
\hline 1992 & $\begin{array}{l}\text { Hubb fi hayy al-safīh / Ṭulū' } \\
\text { al-Muștafá }\end{array}$ & $\begin{array}{l}\text { Circularidad: repetición del título. } \\
\text { Campo semántico final (“finalmente } \\
\text { llegaron a la choza"). Recursos } \\
\text { estilísticos (exclamación). }\end{array}$ \\
\hline 1992 & $\begin{array}{l}\text { Al-Hayy al-balfī / } \\
\text { Muḥammad Zafzāf }\end{array}$ & $\begin{array}{l}\text { Circularidad (mise en abyme); } \\
\text { repetición del título. }\end{array}$ \\
\hline 1992 & $\begin{array}{l}\text { Al-Šutțār (Zaman al-abțtā') / } \\
\text { Muḥammad Šukrī }\end{array}$ & $\begin{array}{l}\text { Carácter incompleto. } \\
\text { Modificación registro (acaba } \\
\text { en un poema). }\end{array}$ \\
\hline 1992 & 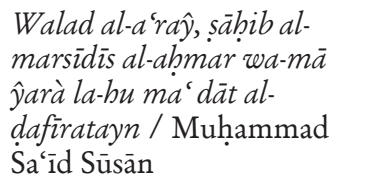 & $\begin{array}{l}\text { Elementos cinéticos finales. } \\
\text { Compleción subordinada. } \\
\text { Expresividad (gritos). Efectos } \\
\text { visuales: fading. }\end{array}$ \\
\hline 1992 & Silistīnā / Yūsuf Fāḍil & Fecha y lugar. Alusiones al futuro. \\
\hline 1993 & $\begin{array}{l}\text { Hikāyat wahm magribiyya / } \\
\text { Ạmmad al-Madīnī }\end{array}$ & $\begin{array}{l}\text { Campo semántico "final” (“qabl } \\
\text { al-widd" } \bar{a} ") \text {. Mayor expresividad y } \\
\text { construcción sintáctica (ausencia de } \\
\text { punto y seguido durante páginas). }\end{array}$ \\
\hline 1993 & $\begin{array}{l}\text { Baḥr al-zalamāt / } \\
\text { Mụhammad al-Dagmūmī }\end{array}$ & $\begin{array}{l}\text { Elementos cinéticos finalizadores. } \\
\text { Compleción subordinada. } \\
\text { Circularidad: repetición del título. }\end{array}$ \\
\hline 1993 & 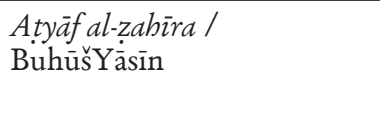 & $\begin{array}{l}\text { Párrafo final. Compleción } \\
\text { subordinada (se sienta a abrir la caja, } \\
\text { la abre y encuentra fotos). }\end{array}$ \\
\hline 1993 & $\begin{array}{l}\text { Al-Fuqdān / 'Abd al-Rahịm } \\
\text { Bahīr }\end{array}$ & $\begin{array}{l}\text { Recurso tipográfico. Compleción } \\
\text { subordinada. Circularidad: } \\
\text { repetición del título. }\end{array}$ \\
\hline
\end{tabular}

1993 Mihan al-fatà Zayn Šàmma / Efectos acústicos. Sālim Himmīšs

1993 Sana bayn al-qitārayn / 'Abd al-Wahāb al-Rāmī
Fecha y lugar. Circularidad: título al final (qițār). Proceso cinético final (inicio de viaje). 
AnExo: (continuación)

\begin{tabular}{|c|c|c|}
\hline Año & Novela / Autor & Características / Tipo de final \\
\hline 1994 & $\begin{array}{l}\text { Šurūb fi-l-mirāyāa / 'Abd } \\
\text { al-Karīm Gallāb }\end{array}$ & $\begin{array}{l}\text { Circularidad: repetición del título. } \\
\text { Elementos cinéticos hacia una meta } \\
\text { final. }\end{array}$ \\
\hline 1994 & $\begin{array}{l}\text { Tarīq al-saḅāb / Ahmmad al- } \\
\text { Madīnī }\end{array}$ & $\begin{array}{l}\text { Circularidad: repetición del título. } \\
\text { Finaliza con parlamento del } \\
\text { personaje. }\end{array}$ \\
\hline 1994 & $\begin{array}{l}\text { Wa-halumma šarrāa / } \\
\text { Muhammad Ḥaŷū }\end{array}$ & $\begin{array}{l}\text { Campo semántico final. Recurso } \\
\text { retórico: acertijo con respuesta } \\
\text { absurda. }\end{array}$ \\
\hline 1994 & $\begin{array}{l}\text { Zaman al-Šärwiya / Šu'ayb } \\
\text { Ḥalífí }\end{array}$ & $\begin{array}{l}\text { Circularidad: repetición del título. } \\
\text { Campo semántico "final”; resumen. }\end{array}$ \\
\hline 1994 & $\begin{array}{l}\text { Bāb Tāazō / 'Abd al-Qādir } \\
\text { al-Š́āwi }\end{array}$ & $\begin{array}{l}\text { Tipografía. Epílogo. Nuevo } \\
\text { comienzo. }\end{array}$ \\
\hline 1994 & $\begin{array}{l}\text { Al-taslīm /'Abd Allāh al- } \\
\text { Hamdūs̄ì }\end{array}$ & $\begin{array}{l}\text { Compleción subordinada (batalla). } \\
\text { Frase final. }\end{array}$ \\
\hline 1994 & $\begin{array}{l}\text { Raml fì al-däkira / Ahmad } \\
\text { Ŷazūlī }\end{array}$ & $\begin{array}{l}\text { Cambio situación narrativa (voz del } \\
\text { narrador). Circularidad: repetición } \\
\text { del título ("es un grano de arena en } \\
\text { la memoria del mar"). }\end{array}$ \\
\hline
\end{tabular}

1995 Halūsāt taršǐšs / Hasūna al- Elemento cinético final (se oculta Miṣbāhī en el horizonte). Compleción subordinada: huida al desierto.

1995 Šâyarat al-bualläta / al-Mīlūdī Compleción subordinada; Šagmūn elementos cinéticos. Anuncio de carácter no anuncio.

1995 Miñà al-ḩazz al-abìr / Idrīs Tipografía. Fijación de la imagen. al-Sagìr y 'Äbd al-Hamīd Anuncio. al-Garbāwì

1995 Firāq fì Tanŷa / 'Abd alHayy Muwaddan

Circularidad. Anuncio continuación.

1996 Zagārìd al-mawt / 'Abd al- Fecha y lugar. Circularidad: título Karīm Ŷuyțī al final. Fijación de imagen o escena. Motivo apocalíptico.

1996 Al-Hî̀̃äb / Hasan Naŷmī

Tipografía. Resumen de la continuación. Freezing. 
ANExo: (continuación)

\begin{tabular}{|c|c|c|}
\hline Año & Novela / Autor & Características / Tipo de final \\
\hline 1996 & $\begin{array}{l}\hat{Y} \text { asad wa-madina / Zahūr } \\
\text { Karam }\end{array}$ & $\begin{array}{l}\text { Tipografía. Atmósfera } \\
\text { patética. Circularidad: mención } \\
\text { del título. }\end{array}$ \\
\hline 1996 & $\begin{array}{l}\text { Zaman al-ahlām al-dāà'‘ / } \\
\text { 'Abd al-Salām Sulaymān }\end{array}$ & $\begin{array}{l}\text { Compleción subordinada. } \\
\text { Simbolismo y atmósfera } \\
\text { patética. Recursos estilísticos } \\
\text { (interrogaciones). }\end{array}$ \\
\hline 1996 & Al-Barwm / 'Ā'yša Mūqiz & $\begin{array}{l}\text { Circularidad: título al final (Buma). } \\
\text { Reiteración de palabras. Campo } \\
\text { semántico ("cerrar los labios", } \\
\text { "ahogar la voz"). }\end{array}$ \\
\hline 1996 & 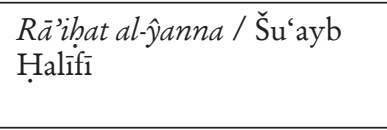 & $\begin{array}{l}\text { Circularidad: mención del título. } \\
\text { Visión al futuro. Resonancia: } \\
\text { descripción de paisaje. }\end{array}$ \\
\hline 1996 & $\begin{array}{l}\text { Malik al-yabūd / Yūsuf } \\
\text { Fāḍil }\end{array}$ & $\begin{array}{l}\text { Cambio del modo discursivo: } \\
\text { de diálogo a narración escena. } \\
\text { Freezing. }\end{array}$ \\
\hline 1996 & $\begin{array}{l}\hat{Y} \text { Ynàubal-rūḥ / Muḥammad } \\
\text { al-Ašsarì }\end{array}$ & Compleción subordinada. \\
\hline 1997 & 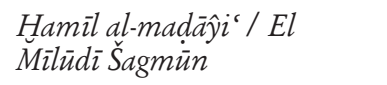 & $\begin{array}{l}\text { Cambio del modo discursivo. } \\
\text { Retrospección, resumen. }\end{array}$ \\
\hline 1997 & $\begin{array}{l}\text { Al-Azmina al-Saba'a / } \\
\text { Muhammad al-Ihsāynī }\end{array}$ & $\begin{array}{l}\text { Tipografía. Cambio de situación } \\
\text { narrativa. }\end{array}$ \\
\hline 1997 & Al-'Allāma / Sālim Ḥimmīš & $\begin{array}{l}\text { Resonancia del final: visión } \\
\text { simbólica. }\end{array}$ \\
\hline 1998 & $\begin{array}{l}\text { Mahāwē al-bulm / } \\
\text { Muhạmmad 'Izz al-Dīn al- } \\
\text { Tāzí }\end{array}$ & $\begin{array}{l}\text { Fecha y lugar. Lema resumen. } \\
\text { Fin proceso. }\end{array}$ \\
\hline 1998 & $\begin{array}{l}\text { Afrwāh wäsi'a / Muḥammad } \\
\text { Zafzāf }\end{array}$ & $\begin{array}{l}\text { Compleción subordinada. } \\
\text { Elementos cinéticos. }\end{array}$ \\
\hline 1998 & $\begin{array}{l}\text { A-yantafi' al-ḥariqq? / 'Alī } \\
\text { Afîlāl }\end{array}$ & $\begin{array}{l}\text { Cierre }=\text { desenlace. Campo } \\
\text { semántico final (muerte). Fecha } \\
\text { y lugar. }\end{array}$ \\
\hline
\end{tabular}

1998 Šnŷyrat hannā’ wa-qamr / Resumen. Carácter epilogal. Aḥmad ai-Tawfīq 
ANExo: (continuación)

\begin{tabular}{|c|c|c|}
\hline Año & Novela / Autor & Características / Tipo de final \\
\hline 1998 & Al-Sayl / Aḥmad al-Tawfīq & $\begin{array}{l}\text { Anuncio paratextual del final } \\
(\text { tammat }) \text {. Resumen. }\end{array}$ \\
\hline 1998 & Gìla / 'Abdallāh al-Laruwī & $\begin{array}{l}\text { Anagnórisis. Campo semántico } \\
\text { final. Relatividad del carácter } \\
\text { concluso. }\end{array}$ \\
\hline 1998 & $\begin{array}{l}\text { Burŷal-su'īd / Mubārak } \\
\text { Rabī's }^{-6}\end{array}$ & $\begin{array}{l}\text { Relatividad del carácter concluso. } \\
\text { Ritmo acelerado y frases } \\
\text { entrecortadas. }\end{array}$ \\
\hline 1998 & $\begin{array}{l}\text { Maqbarat al-sa'āda / 'Abd } \\
\text { Allāh Zurayqa }\end{array}$ & $\begin{array}{l}\text { Lugar y fecha. Fading y freezing. } \\
\text { Campo semántico "final" } \\
\text { ("extinguirse"). }\end{array}$ \\
\hline 1999 & $\begin{array}{l}\text { Al-Säḥa al-šararafizyya / 'Abd } \\
\text { al-Qädir al-S̄āwī }\end{array}$ & Resumen epilogal. \\
\hline 1999 & $\begin{array}{l}\text { Ŷirāh al-rūh wa-l-hasad / } \\
\text { Malīịa Mustazrifa }\end{array}$ & $\begin{array}{l}\text { Elemento cinético final. Alusiones } \\
\text { al futuro. }\end{array}$ \\
\hline 2000 & $\begin{array}{l}\text { Garibat al-Husayn / Ahmad } \\
\text { al-Tawfīq }\end{array}$ & $\begin{array}{l}\text { Circularidad: título al final. } \\
\text { Compleción subordinada. }\end{array}$ \\
\hline 2000 & $\begin{array}{l}\text { Fitnat al-ru'ūs wa-l-niswa / } \\
\text { Sālim Ḥimmīs }\end{array}$ & $\begin{array}{l}\text { Circularidad: autocita del íncipit; } \\
\text { repetición del acto de enunciación. }\end{array}$ \\
\hline 2000 & $\begin{array}{l}\text { Sìrat al-rimād / Huadîya } \\
\text { Meruāzī }\end{array}$ & $\begin{array}{l}\text { Anuncio de continuación. Recursos } \\
\text { estilísticos: (pregunta, sintaxis } \\
\text { particular). }\end{array}$ \\
\hline 2000 & Al-Haref / 'Alī Afìlālī & $\begin{array}{l}\text { Fecha y lugar. Circularidad: título } \\
\text { al final. Campo semántico (muerte). } \\
\text { Anticipación. }\end{array}$ \\
\hline 2000 & Hašǐš / Yūsūf Fāḍil & $\begin{array}{l}\text { Fecha. Cambio de modo discursivo: } \\
\text { paso a descripción de la escena final } \\
\text { ("llevarse lo que dejó el verano"). }\end{array}$ \\
\hline
\end{tabular}

